\begin{tabular}{|c|c|c|c|c|}
\hline JURNAL & \multirow{2}{*}{ VOLUME 1 } & NOMOR 2 & HALAMAN 70-141 & $\begin{array}{l}\text { ISSN 2655-8823 }(p) \\
\text { ISSN 2656-1786 }(e)\end{array}$ \\
\hline KOLABORASI RESOLUSI KONFLIK & HALA \\
\hline
\end{tabular}

\title{
MODEL PELAYANAN SOSIAL BAGI ANAK KORBAN KEKERASAN
}

\author{
Nandang Mulyana \\ Dosen Prodi Ilmu Kesejahteraan Sosial FISIP-Universitas Padjadjaran \\ E-mail: mulyananandan@yahoo.com \\ Risna Resnawaty \\ Dosen Prodi Ilmu Kesejahteraan Sosial FISIP-Universitas Padjadjaran \\ E-mail: risnaresnawaty@unpad.ac.id \\ Rudy Saprudin Darwis \\ Dosen Prodi Ilmu Kesejahteraan Sosial FISIP-Universitas Padjadjaran \\ E-mail: rsdarwis@gmail.com
}

\begin{abstract}
ABSTRAK
Anak merupakan anugerah yang diberikan Tuhan kepada manusia. Akan tetapi dalam perkembangannya anak seringkali menjadi korban kekerasan. Kekerasan terhadap anak mempunyai dampak yang sangat luas dan panjang. Anak korban kekerasan akan membawa trauma selama hidupnya. Di sisi lain korban kekerasan semasa kecil mempunyai potensi untuk menjadi pelaku pada masa yang akan dating sewaktu korban tersebut telah dewasa. Trauma yang luas dan panjang ini harus mendapatkan penanganan secara komprehensif. Faktor penyebab terjadinya kekerasan terhadap anak adalah faktor internal dan faktor eksternal. Faktor internal adalah faktor yang berasal dari dalam keluarga. Sementara faktor eksternal adalah faktor yang terjadi diluar lingkungan keluarga. Penanganan terhadap anak korban kekerasan yang komprehensif, sehingga diperlukan adanya model pelayanan sosial bagi anak korban kekerasan. Model pelayanan sosial bagi anak korban kekerasan dapat dilihat dari cakupan dan kesinambungannya, maupun pemberi pelayanan sosial yang diberikan. Jadi dengan demikian untuk mendapatkan pelayanan yang komprehensif bagi anak korban kekerasan diperlukan koordinasi antarlembaga pemberi pelayanan sosial. Penanganan bagi anak korban kekerasan dengan peningkatan koordinasi antarlembaga yang memberikan pelayanan bagi anak korban kekerasan. Koordinasi ini menjadi penting dengan tujuan untuk menghindari pelayanan yang diberikan tumpang tindih. Selain itu juga dengan koordinasi pelayanan sosial yang diberikan akan lebih menyeluruh. Koordinasi juga akan melihat pelayanan yang sudah diberikan serta yang dibutuhkan oleh anak korban kekerasan. Kemudian koordinasi juga dapat melihat pelayanan sosial yang dimiliki oleh masing-masing instansi yang memberikan pelayanan sosial bagi anak korban kekerasan.
\end{abstract}

Kata kunci; Kekerasan terhadap anak, model penanganan.

\section{PENDAHULUAN}

Anak merupakan harapan yang ditunggu kehadirannya bagi setiap keluarga. Hal ini dikarenakan anak dapat menjadi perekat bagi keluarga yang bersangktan. Selain itu anak juga merupakan generasi penerus bagi keberlangsungan dari keluarga bahkan masyarakat. Tingginya harapan terhadap anak ini menjadikan anak harus dilindungi dari segala bentuk perlakuan tidak manusiawi yang mengakibatkan terjadinya pelanggaran hak asasi manusia (Apsari, 2015; 67). Anak berhak atas kelangsungan hidup, tumbuh dan berkembang serta berhak atas perlindungan dari kekerasan dan diskriminasi sebagaimana diamanatkan dalam Undang-Undang Dasar Negara Republik Indonesia Tahun 1945.

Anak yang seharusnya mendapatkan perlindungan, dalam kenyataannya sering mendapatkan perlakuan yang tidak baik. Data menunjukkan bahwa kasus kekerasan terhadap anak masih tinggi. Komisi Nasional Perlindungan Anak (2015) menunjukkan bahwa Indonesia berada pada posisi darurat kekerasan terhadap anak dalam lima tahun terakhir (2010-2015). Pada tahun 2013, tercatat 2.676 kasus kekerasan terhadap anak dengan $54 \%$ dari kasus kekerasan terhadap anak merupakan kejahatan seksual. Tahun 2014, tercatat 


\begin{tabular}{|c|c|c|c|c|}
\hline JURNAL & \multirow{2}{*}{ VOLUME 1 } & NOMOR 2 & HALAMAN 70-141 & $\begin{array}{l}\text { ISSN 2655-8823 }(p) \\
\text { ISSN 2656-1786 }(e)\end{array}$ \\
\hline KOLABORASI RESOLUSI KONFLIK
\end{tabular}

2.737 kasus kekerasan terhadap anak yang $52 \%$ dari kasus kekerasan terhadap anak adalah kejahatan seksual. Sementara itu pada tahun 2015, Pusat Data dan Informasi (Pusdatin) Komnas Anak menerima 2.898 kasus kekerasan terhadap anak. Dari 2.898 kasus yang dikemukakan oleh Pusdatim Komnas Anak tersebut, 60 persennya merupakan kasus kejahatan seksual. Sisanya, 40 persen lainnya adalah kekerasan fisik, penelantaran, penganiayaan, pemerkosaan, adopsi ilegal, penculikan, perdagangan anak untuk eksploitasi seksual atau ekonomi, tawuran, dan kasus narkoba. (www.Kompas.com, diakses 20 Mei2016). Sementara itu ditinjau dari lokasi terjadinya kekerasan terhadap anak, data menunjukkan bahwa ada 62 persen kekerasan terhadap anak terjadi di lingkungan terdekat keluarga dan lingkungan sekolah, selebihnya 38 persen di ruang publik (www.news.liputan6 .com diakses 20 Januari 2018).

Kekerasan terhadap anak juga terjadi di Jawa Barat. Pusat Pelayanan Terpadu Pemberdayaan Perempuan dan Anak (P2TP2A) Jawa Barat, menyatakan, sepanjang periode 2010-2015 pihaknya telah menangani sebanyak 946 kasus. (www. Kompas.com, diakses 20 Mei 2016). Banyaknya kasus yang ditangani oleh P2TP2A memperlihatkan bahwa di Jawa Barat kasus kekerasan terhadap anak ini tergolong tinggi. Data yang diperoleh P2TP2A ini hanyalah sebagian kecil dari kasus kekerasan terhadap anak yang terjadi sebenarnya. Hal ini dikarenakan tidak semua kasus kekerasan terhadap anak dilaporkan. Bahkan ibarat fenomena gunung es, bahwa kekerasan terhadap anak yang terlihat hanyalah sebagian kecil dari kasus yang sebenarnya terjadi.

Kasus kekerasana terhadap anak ini perlu mendapatkan pelayanan yang komprehensif. Pelayanan yang komprehensif bagi anak yang mengalami kekerasan tidak hanya dilakukan oleh pemerintah saja tetapi juga harus melibatkan semua elemen termasuk masyarakat. Pelibatan semua eleman ini tentunya agar kekerasan terhadap anak dapat berkurang. Pelayanan terhadap anak korban kekerasan tidak hanya pelayanan fisik tetapi juga pelayanan yang lebih luas lagi. Pelayanan kekersan terhadap anak baik itu korban maupun pelaku harus melibatkan semua pihak dan meliputi semua aspek dari pendidikan, kesehatan, dan aspek lainnya. Demikian juga pemberi pelayanan tidak hanya pemerintah, tetapi juga lembaga yang peduli sampai masyarakat.

Pemberian pelayanan terhadap anak korban kekerasan ini memerlukan adanya model yang dapat digunakan. Model pelayanan ini juga dapat melihat keterlibatan elemen yang ada dalam memberikan pelayanan terhadap anak korban kekerasan. Model yang dikembangkan ini disesuaikan dengan konsep yang ada. Jadi dengan demikian model pelayanan terhadap anak korban kekerasan ini menjadi pedoman dalam memberikan pelayanan terhadap anak korban kekerasana.

\section{PEMBAHASAN}

Model pelayanan dalam penanganan terhadap anak korban kekerasan tidak terlepas dari berbagai penyebab terjadinya kekerasan tersebut. Implementasi model ini tidak terlepas dari anak korban kekerasan. Faktor penyebab menjadi penting dalam mengimplementasikan pelayanan yang akan diberikan kepada anak yang mengalami kekerasan. Dengan demikian untuk melihat model pelayanan yang diberikan ada baiknya membahas terlebih dahulu faktor yang menjadi penyebab terjadinya kekerasan terhadap anak.

\section{Faktor Penyebab Kekerasan terhadap Anak}

Anak adalah seseorang yang belum berusia 18 tahun, termasuk anak yang masih dalam kandungan. Definisi ini tertuang dalam Undang-Undang Nomor 35 Tahun 2014 tentang Perubahan Atas Undang-Undang Nomor 23 Tahun 2002 tentang Perlindungan Anak, Pasal 1. Selanjutnya pada Pasal 1 Ayat (2) berkaitan 


\begin{tabular}{|c|c|c|c|c|}
\hline JURNAL & \multirow{2}{*}{ VOLUME 1 } & NOMOR 2 & HALAMAN 70-141 & $\begin{array}{l}\text { ISSN 2655-8823 }(p) \\
\text { ISSN 2656-1786 }(e)\end{array}$ \\
\hline KOLABORASI RESOLUSI KONFLIK
\end{tabular}

dengan Perlindungan Anak. Perlindungan Anak adalah segala kegiatan untuk menjamin dan melindungi anak dan hakhaknya agar dapat hidup, tumbuh, berkembang, dan berpartisipasi secara optimal sesuai dengan harkat dan martabat dan martabat kemanusiaan, serta mendapat perlindungan dari kekerasan dan diskriminasi.

Hak anak termasuk anak korban kekerasan harus dipenuhi. Hal ini dikarenakan Indonesia sebagai salah satu negara yang meratifikasi Convention on the Rights of the Child atau Konvensi Hak Anak (KHA). Indonesia meratifikasi konvensi hak anak (KHA) berdasarkan
Keputusan Presiden Nomor 36 Tahun 1990 (rightsvoiceofchildren diakses 21 Desember 2017). Dengan meratifikasi konvensi hak anak tersebut, Indonesia mempunyai kewajiban untuk menjalankan hak anak. Sebagaimana diamanatkan pada substansi terkait hak anak, salah satu yang dipromosikan dalam Konvensi Hak Anak adalah prinsip proteksi sosial. Setiap anak memiliki hak atas perlindungan hidup (Pasal 6).

Anak juga mempunyai berbagai hak. United Nations Convention on the Right of the Child mengklasifikasikan hak anak sebagai berikut:

Tabel 1. Klasifikasi Hak Anak

Menurut United Nations Convention on the Rights of the Child

\begin{tabular}{|c|l|l|}
\hline No & \multicolumn{1}{|c|}{$\begin{array}{l}\text { Klasifikasi } \\
\text { Hak Anak }\end{array}$} & \multicolumn{1}{|c|}{ Keterangan } \\
\hline 1 & Survival Rights & $\begin{array}{l}\text { Pemenuhan kebutuhan hak dasar dalam kehidupan } \\
\text { seperti pemenuhan nutrisi, tempat tinggal, } \\
\text { pelayanan standar layak dalam kehidupan, dan } \\
\text { akses pelayanan kesehatan }\end{array}$ \\
\hline 2 & $\begin{array}{l}\text { Development } \\
\text { Rights }\end{array}$ & $\begin{array}{l}\text { Hak pendidikan, bermain, akses informasi, } \\
\text { kebebasan berpikir, hak atas kesadaran, dan } \\
\text { beragama }\end{array}$ \\
\hline 3 & $\begin{array}{l}\text { Protection } \\
\text { Rights }\end{array}$ & $\begin{array}{l}\text { Hak keamanan dari segala bentuk kekerasan, } \\
\text { penelantaran, dan ekploitasi, }\end{array}$ \\
\hline 4 & $\begin{array}{l}\text { Participation } \\
\text { Rights }\end{array}$ & $\begin{array}{l}\text { Hak berpendapat, partisipasi, meningkatkan } \\
\text { kapasitas secara baik ketika memperoleh } \\
\text { kesempatan di dalam masyarakat, terutama } \\
\text { mempersiapkan masa depan menuju tahap } \\
\text { perkembangan di masa remaja dan dewasa. }\end{array}$ \\
\hline
\end{tabular}

Sumber : Data diolah dari United Nations Convention on the Rights of the Child, Tahun 1989

Berdasarkan table tersebut terlihat bahwa hak anak itu sangat luas. Hak anak itu dari mulai hak yang paling dasar seperti hak untuk hidup sampai hak untuk dipersiapkan masa depannya. Jadi hak anak itu tidak hanya hak untuk mendapatkan perlindungan terhadap hidupnya juga masyarakat khususunya orang tua harus mampu untuk mempersiapkan anak tersebut untuk mandiri di masa depan.

Kompleksnya hak yang dimiliki oleh anak ini membuka ruang bagi pihak lain untuk melangarnya. Data dari Komisi Perlindungan Anak Indonesia (KPAI) mencatat terjadi peningkatan sekitar 1.000 kasus kekerasan pada tahun 2016. Dari data tersebut, terdapat sekitar 136 kasus kekerasan terhadap anak yang disebabkan oleh pengaruh media sosial. Pesatnya perkembangan teknologi menjadi salah satu faktor terjadinya kekerasan terhadap anak. Kekerasan terhadap anak yang disebabkan karena media sosial diantaranya kasus bullying. Kekerasan terhadap anak ini 


\begin{tabular}{|c|c|c|c|c|}
\hline JURNAL & \multirow{2}{*}{ VOLUME 1 } & \multirow{2}{*}{ NOMOR 2 } & HALAMAN 70-141 & $\begin{array}{l}\text { ISSN 2655-8823 }(p) \\
\text { ISSN 2656-1786 }(e)\end{array}$ \\
KOLABORASI RESOLUSI KONFLIK & H
\end{tabular}

mengalami peni9ngkatan setiap tahunnya. Menurut data KPAI, angka kekerasan terhadap anak dalam beberapa tahun belakangan relatif menunjukan tren peningkatan. Hasil temuan KPAI dari 2011 sampai 2014, terjadi peningkatan secara signifikan, yaitu tahun 2011 (2178 kasus),
2012 (3512 kasus), 2013 (4311 kasus), dan 2014 (5066 kasus).

Kekerasan terhadap anak dapat dialami dengan berbagai bentuk. Galtung membuat tipologi bentung kekerasan terhadap anak sebagai berikut :

Tabel 2. Tipologi Kekerasan Menurut Johan Galtung

\begin{tabular}{|c|c|c|c|c|}
\hline \multicolumn{3}{|c|}{ Violence typology according to Galtung } & \multicolumn{2}{|c|}{ Need Groups } \\
\hline $\begin{array}{l}\text { Survival } \\
\text { (Negation: } \\
\text { death) }\end{array}$ & $\begin{array}{l}\text { Well-being } \\
\text { (Negation: } \\
\text { poverty, } \\
\text { illness) }\end{array}$ & $\begin{array}{l}\text { Identity / } \\
\text { purpose } \\
\text { (Negation: } \\
\text { alienation) }\end{array}$ & $\begin{array}{l}\text { Freedom } \\
\text { (Negation: } \\
\text { oppression) }\end{array}$ & \\
\hline Direct violence & Killing & $\begin{array}{l}\text { Injury, siege, } \\
\text { sanctions, } \\
\text { poverty }\end{array}$ & $\begin{array}{l}\text { De-socialization, } \\
\text { re-socialization, } \\
\text { underclass }\end{array}$ & $\begin{array}{l}\text { Repression, } \\
\text { imprisonment, } \\
\text { expulsion, } \\
\text { deportation }\end{array}$ \\
\hline $\begin{array}{l}\text { Structural } \\
\text { Violence }\end{array}$ & Exploitation A & Exploitation B & $\begin{array}{l}\text { Penetration, } \\
\text { segmentation }\end{array}$ & $\begin{array}{l}\text { Marginalization, } \\
\text { fragmentation }\end{array}$ \\
\hline
\end{tabular}

Sumber: Data diolah dari http://www.friedenspaedagogik.de/content/pdf/2754

Dalam memahami karakteristik kekerasan, dapat ditelusuri melalui pandangan Galtung, yaitu penjelasan berupa klasifikasi kekerasan yang terbagi dalam dua bentuk yaitu kekerasan langsung dan kekerasan struktural. Kekerasan langsung memposisikan korban sebagai objek dari kekerasan, seperti kasus pembunuhan, yang menyebabkan korban kehilangan nyawa. Kemudian, pemahaman kekerasan struktural lebih pada penindasan dari subjek terhadap objek, namun dipengaruhi oleh struktur atau dominasi di dalam tatanan masyarakat. Misalnya, seperti dikemukakan Galtung, ekploitasi dari subjek terhadap objek (korban) dan dampak yang dirasakan korban adalah terjadi marginalisasi atau terasing.

Kasus kekerasan terhadap anak disebabkan beberapa faktor penyebab. Berdasarkan data yang ada faktor penyebab terjadinya kekersan terhadap anak terbagi atas faktor internal dan faktor eksternal (Mulyana, Resnawaty, Basar, 2017). Faktor internal terjadinya kekerasan terhadap anak adalah faktor keluarga. Faktor keluarga ini tidak hanya berkaitan dengan korban kekerasan tetapi juga pelaku kekerasan. Hasil survey kekerasan terhadap anak (SKTA) tahun 2013 menunjukkan bahwa pelaku kekerasan dalam keluarga dilakukan oleh orang tua baik ayah maupun ibu dan kerabat. Faktor keluarga ini berhubungan dengan ekonomi keluarga dan kondisi keluarga. Keluarga dengan ekonomi yang tidak baik akan mendorong orang tua baik itu ayah, ibu, maupun keduanya untuk pergi mencari pekerjaan dengan meninggalkan keluarga. Anak-anak ditinggalkan baik itu dengan ayah/ibu maupun dengan anggota keluarga lainnya. Kurangnya perhatian terhadap anak menyebabkan anak menjadi korban kekerasan atau menjadi pelaku kekerasan terhadap anak lainnya. Anak korban kekerasan pun pada dasarnya dilakukan oleh orang-orang terdekat dengan anak atau keluarga (Mulyana, Resnawaty, Basar, 2017).

Selain ekonomi, faktor keharmonisana keluarga juga menjadi faktor terjadinya kekerasan terhadap anak. Keluarga yang tidak harmonis cenderung terjadi kekerasan 


\begin{tabular}{|c|c|c|c|c|}
\hline JURNAL & \multirow{2}{*}{ VOLUME 1 } & NOMOR 2 & HALAMAN 70-141 & $\begin{array}{l}\text { ISSN 2655-8823 }(p) \\
\text { ISSN 2656-1786 }(e)\end{array}$ \\
\hline KOLABORASI RESOLUSI KONFLIK & H
\end{tabular}

terhadap anak baik dilakaukan oleh orang tua maupun saudara (Rahmat, 2016). Ayah dan ibu yang tidak harmonis cenderung bersikap tidak peduli dengan anakanaknya. Orang tua sibuk dengan permasalahan yang dihadapinya. Dengan demikian orang tua menjadi lalai dengan perkembangan dan pergaulan anakanaknya. Anak-anak yang butuh perhatian dan perlindungan selanjutnya mencari diluar rumah. Dengan demikian anak menjadi rentan untuk menjadi korban kekerasan atau menjadi pelaku kekerasan terhadap anak-anak lainnya. Anak pelaku kekerasan pada dasarnya melampiaskan kekecewaannya serta menjadikan kekerasan sebagai sarana untuk mencari perhatian baik dari orang tuanya maupun dari masyarakat sekitar.

Sementara faktor eksternal lebih kepada lingkungan pergaulan dan perkembangan teknologi. Kekerasan terhadap anak yang berhubungan dengan lingkungan justru terjadi dilingkungan sekolah. Perilaku saling ejek merupakan awal terjadinya kekerasan terhadap anak. Dari saling ejek itulah selanjutnya terjadi bullying. Perilaku bullying ini sangat sering terjadi pada insitusi pendidikan, mulai dari SD sampai perguruan tinggi. Bullying terjadi karena adanya perasaan senioritas pelaku terhadap korbannya. Oleh sebab itu perilaku bullying ini pada umunya dilakukan oleh siswa/mahasiswa senior terhadap juniornya. Faktor lingkungan lainnya yang dapat mendorong terjadinya kekerasan terhadap anak adalah kasus tawuran. Tawuran antarsekolah pada umunya tidak pernah didasari oleh hal besar. Tawuran lebih banyak dikarenakan hal sepele dan diturunkan dari kakak kelasnya.

Faktor eksternal lainnya yang dapat menyebabkan terjadinya tindak kekerasan adalah teknologi. Media sosial dan berbagai game kekerasan mendorong anakanak untuk mempraktikkanya dengan teman-temannya. Rasa ingin tahu yang sangat besar dalam diri anak-anak mendorong anak-anak untuk mencoba meniru apa yang dilihatnya. Demikian juga dengan mudahnya anak-anak untuk mengakses media sosial setiap saat anakanak dapat membuka adegan-adegan yang berbau kekerasan. Dengan demikian anakanak menjadi terbiasa dengan tindak kekerasan. Akibatnya seringkali kasus kekerasan terjadi karena kebiasaan.

\section{Model Penanganan terhadap Anak Korban Kekerasan}

Kekerasan terhadap anak akan mempunyai dampak yang sangat panjang. Anak akan terus mengingat kejadian kekerasan yang pernah dialaminya. Anak yang mengalami kekerasan mempunyai kecenderungan setelah dewasa akan menjadi pelaku kekerasan bagi anak yang lainnya. Dengan kondisi ini maka penanganan terhadap anak korban kekerasan menjadi suatu hal yang harus dilakukan. Penanganan terhadap anak yang mengalami kekerasan harus melibatkan berbagai stakeholders. Untuk memberikan penanganan terhadap anak korban kekerasan diperlukan adanya model yang menjadi patokan dalam penanganan terhadap anak korban kekerasan.

Penanganan kekerasan terhadap anak dapat dilakukan dengan berbagai perspektif. Penanganan terhadap anak korban kekerasan tidak terlepas dari pelayanan yang diberikan. Suharto (2006) melihat bahwa penanganan bagi anak korban kekerasan dengan memberikan pelayanan sosial. Pelayanan sosial dalam penanganan bagi anak korban kekerasan dapat dilihat dari perspektif residual dan institusional. Perspekrif residual melihat bahwa penanganan tersebut diberikan jika kebutuhan individu tidak dapat dipenuhi dengan baik oleh lembaga yang ada dalam masyarakat seperti keluarga. Penanganan dapat dihentikan jika individu dapat berfungsi kembali. Sedangkan pespektif institusional memandang penanganan sebagai charity for unfortunates. Penanganan merupakan hak setiap warga masyarakat. jadi dengan demikian penanganan terhadap anak korban kekerasan merupakan suatu keharusan. 


\begin{tabular}{|c|c|c|c|c|}
\hline JURNAL & \multirow{2}{*}{ VOLUME 1 } & NOMOR 2 & HALAMAN 70-141 & $\begin{array}{l}\text { ISSN 2655-8823 }(p) \\
\text { ISSN 2656-1786 }(e)\end{array}$ \\
\hline KOLABORASI RESOLUSI KONFLIK & HALA \\
\hline
\end{tabular}

Setiap anak korban kekerasan harus mendapatkan penanganan.

Berdasarkan kelompok maupun perspektifnya, maka penanganan yang diberikan mencakup tiga hal yaitu:

a. Equally distributed, yaitu penanganan harus mencakup dan distribusinya menjangkau semua segmen secara merata.

b. Accountably delivered yang menunjukkan bahwa penanganan harus mempunyai kualitas yang dapat diandalkan

c. Sustainably provided melihat bahwa penanganan harus diberikan secara melembaga dan berkelanjutan.

Cakupan penangnan yang diberikan tersebut mendorong terciptanya strategi yang dapat dijadikan model dalam memberikan pelayanan sosial (Suharto, 2006) yaitu:

1. Dari Residual-selekrif ke institusional-universal

Didasarkan kepada cakupan dari pelayanan sosial serta keberlanjutan pelayanan sosial yang diberikan maka pelayanan sosial dapat diklasifikasikan ke dalam empat model (Suharto, 2006) yaitu:

a. Model residual-universal yang melihat bahwa pelayanan sosial harus diberikan secara parsial namun pelayanan yang diberikan harus mencakup banyak penerima.

b. Model institusional-universal, melihat bahwa pelayanan sosial diselenggarakan melembaga dan berkelanjutan dengan mempunyai cakupan yang luas.

c. Model residual-selektif yang melihat pelayanan sosial harus diberikan secara parsial dan diberikan kepada kelompok terbatas serta berjangka pendek.

d. Model residual-institusional yang melihat pelayanan sosial diberikan secara melembaga dan berkelanjutan.
Keempat model pelayanan sosial tersebut jika digambarkan sebagai berikut :

\begin{tabular}{|c|c|c|}
\hline \multirow[t]{3}{*}{ cakupan } & $\begin{array}{l}\text { Residual } \\
\text {-Universal }\end{array}$ & $\begin{array}{l}\text { Institusioal } \\
\text {-Uhiversal }\end{array}$ \\
\hline & $\begin{array}{l}\text { Residual } \\
\text {-Selektif }\end{array}$ & $\begin{array}{l}\text { Residual } \\
\text {-Institusional }\end{array}$ \\
\hline & & Keberlanjutan \\
\hline
\end{tabular}

Gambar 1 : Model Pelayanan sosial berdasarkan cakupan dan keberlangsungan

Berdasarkan cakupan dan keberlangsungan pelayanan sosial bagi anak yang mengalami kekerasan maka pelayanan sosial yang diberikan tidak hanya sewaktu terjadi tindak kekerasan. Pelayanan sosial dalam rangka penanganan terhadap anak korban kekerasan juga harus dilakukan sebelum tindak kekerasan itu terjadi. Upayaupaya preventif untuk mencegah terjadinya tindak kekerasan terhadap anak harus dilakukan. Jadi dengan demikian pelayanan sosial dalam penanganan anak korban kekerasan dapat diberikan kepada anak yang telah mengalami tindak kekerasan serta upaya untuk mencegah terulangnya tindak kekerasan pada masa yang akan datang.

Selanjutnya penanganan terhadap anak korban kekerasan juga dapat dilakukan secara individual maupun kelompok. Penaganan dengan memberikan pelayanan secara invidual dapat dilakukan jika kekerasan yang terjadi dapat membawa dampak yang mendalam bagi anak korban kekerasan. Selain itu tindak kekerasan yang terjadi juga dapat membawa aib baik bagi anak itu sendiri maupun pihak keluarga. Sementara itu pelayanan sosial yang bersifat kelompok dapat dilakukan 


\begin{tabular}{|c|c|c|c|c|}
\hline JURNAL & \multirow{2}{*}{ VOLUME 1 } & NOMOR 2 & HALAMAN 70-141 & $\begin{array}{l}\text { ISSN 2655-8823 }(p) \\
\text { ISSN 2656-1786 }(e)\end{array}$ \\
\hline KOLABORASI RESOLUSI KONFLIK & HALA \\
\hline
\end{tabular}

jika pelayanan sosial tersebut bersifat preventif. Dengan demikian cakupan yang mendapatkan pelayanan menjadi lebih banyak. Penggunaan kelompok juga dalam upayan kuratif. Anak-anak yang mengalami kekerasan berkumpul dengan membahas permasalahan kekerasan yang dihadapi. Anakanak tersebut berupaya untuk mencari alternatif pemecahan masalah serta pencegahan terjadinya tindak kekerasan terhadap anak. Dengan mempunyai pengalaman yang sama maka diharapkan anak-anak akan berbagi dalam memecahkan masalah kekerasan.

Demikian juga dengan keberlanjutan pelayanan sosial dalam penanganan terhadap anak korban kekerasan. Pelayanan sosial yang diberikan dapat bersifat insidental maupun berkesimambungan. Pelayanan yang bersifat insidental dilakukan jika anak korban kekerasan harus secepatnya mendapatkan pertolongan. Pelayanan tersebut hars diberikan karena mengancam jiwa anak korban kekerasan. Sementara itu, pelayanan sosial berkesimanbungan jika pelayanan sosial dalam penangnan terhadap anak korban kekerasan dalam jangka panjang. Selain itu juga pelayanan berkeseinambungan ini perlu dilakukan untuk mencegah terulangnya tindak kekerasan terhadap anak.

2. Dari problem-based approach ke right-based approach

Pelayanan sosial berbasis masalah pada umumnya bersifat reaktif dimana pelayanan sosial diberikan kepada sekelompok masyarakat yang mengalami masalah atau seringkali disebut sebagai kondisi kedaruratan. Pelayanan sosial yang berbasis masalah ini cenderung eksklusif dan menimbulkan stigma bagi kelompok masyarakat yang menerima pelayanan sosial sebagai penyandang masalah sosial.

Pelayanan sosial berbasis hak lebih bersifat inklusif yakni pelayanan sosial tidak membedabedakan sasaran penerimanya. Pelayanan sosial berbasis hak ini diberikan tidak hanya bersifat perceived needs tetapi juga bersifat strategic needs yang mencakup absolute needs dan normative needs.

Berbeda dengan Suharto (2006) yang mengemukakan model pelayanan sosial berdasarkan cakupan dan keberlanjutan, Spicker (1995) memberikan model yang didasarkan pada penyelenggara pelayanan sosial yaitu pemerintah dan masyarakat termasuk dunia usaha. Berdasarkan penyelenggara pelayanan sosial Spicker (1995) memberikan model sebagai berikut:

a. Model welfare state, yaitu model pelayanan sosial yang didominasi oleh peran pemerintah. Peran masyarakat sangat terbatas.

b. Model welfare pluralism, yaitu model pelayanan sosial dimana peran pemerintah dan masyarakat sebagai penyelenggara pelayanan sosial sama kuat dan seimbang.

c. Model welfare society, yaitu model pelayanan sosial yang penyelenggaraannya

didominasi oleh masyarakat sedangkan peran pemerintah sangat terbatas.

d. Model welfare rudimentalism, yaitu model pelayanan sosial dimana peran pemerintah dan masyarakat sama-sama lemah.

Model pelayanan sosial yang didasarkan pada penyelenggara 


\begin{tabular}{|c|c|c|c|c|}
\hline JURNAL & \multirow{2}{*}{ VOLUME 1 } & NOMOR 2 & HALAMAN 70-141 & $\begin{array}{l}\text { ISSN 2655-8823 }(p) \\
\text { ISSN 2656-1786 }(e)\end{array}$ \\
\hline KOLABORASI RESOLUSI KONFLIK
\end{tabular}

pelayanan sosial ini jika digambarkan sebagai berikut :

Negara

\begin{tabular}{l|r} 
Welfare state & Welfare pluralism \\
\hline $\begin{array}{l}\text { Welfare } \\
\text { rudimentalism }\end{array}$ & $\begin{array}{r}\text { Welfare society } \\
\text { Masyarakat }\end{array}$ \\
\hline &
\end{tabular}

Gambar 2 : Model Pelayanan Sosial berdasarkan Peran Penyelenggaranya

Berdasarkan model yang dikemukakan oleh Spicker (1995) terlihat bahwa pelayanan sosial tidak dapat diserahkan kepada pemerintah maupun masyarakat secara penuh. Dalam penyelenggaraannya masing-masing penyeenggara baik itu pemerintah maupun masyarakat harus berperan. Dengan demikian dalam penyelenggaraan pelayanan sosia ini bersifat cross-cutting (Suharto 2007). Walaupun demikian dalam penyelenggaraan pelayanan sosial ada pihak yang berperan lebih dominan dibandingkan dengan pihak lainnya baik itu pemerintah maupun masysrakat.

Berdasarkan model yang dikemukakan oleh Spicker (1995) terlihat bahwa penanganan terhadap anak korban kekerasan dapat dilakukan oleh satu pihak saja. Akan tetapi, dapat implementasinya perlu adanya keterlbatan berbagai pihak. Pihak pemerintah yangdiwakili oleh dinas sosial, dinas pendidikan, dinas kesehatan kepolisian, kejkasanaa, kehakiman dapat memberikan pelayanan sosial dalam penanganan terhadap anak. Sementara itu masyarakat juga harus berperan dalam penanganan terhadap anak korban kekerasan. Lembaga-lembaga kemasyarakatan sebagai bagian yang berada dalam masyarakat harus mampu mendeteksi terjadinya kekerasan terhadap anak. Lembaga pemerintah dan masyarakat harus mampu memberikan pelaytanan sosial baik itu bersifat preventif, promotif, maupun kuratif kepada anak korban kekerasan.
Selanjutnya berkaitan pihak mana yang harus berperan secara dominan dalam penanganan terhadap anak korban kekerasan tidak dapat ditentukan secara pasti. Pemberian pelayanan sosial bagi anak yang mengalami kekerasan didasarkan kebutuhan anak itu sendiri. Pelibatan lembaga pemerintah dan masyarakat sesuai dengan kebutuhan. Sebagai contoh jika anak mengalami kekerasan fisik maka dinas kesehatan yang paling pertama dan dominan untuk penanganannya. Kemudia seterusnhya disesuaikan dengan tahapan pelayanan maka keterlibatan pihak lain semakin banyak.

Koordinasi antarinstansi baik itu instansi pemerintah maupun masyarakat dalam penanganan terhadap anak korban kekerasan menjadi sangat penting. Hal ini dikarenakan, pertama tidak semua instansi dapat menangani anak korban kekerasan. Kondisi ini dikarenakan terbatasnya berbagai sumber daya baik itu manusia, termasuk ketrampilan, dana, dan waktu. Kedua, banyaknya instansi yang bergerak dalam penanganan terhadap anak korban kekerasan. Dengan demikian perlu adanya pembagian penanganan disesuaikan dengan konpetensi dan wewenang masing-masing. Kurangnya koordinasi antarinsatnsi yang bergerak dalam penanganan terhadap anak korban kekerasan menjadikan pelayanan yang diberikan tidak maksimal. Ketiga, karena tidak mampu menangani anak korban kekerasan sehingga satu instansi untuk merujuk pada instansi lainnya. Untuk melakukan rujukan diperlukan koordinasi. Koordinasi disini tidak hanya berkaitan dengan keberlanjutan pelayanan yang akab diberikan jugamengenai data yang harus disampaikan sehingga dengan demikian telah terjadi peralihan dalam pemberian pelayanan.

\section{PENUTUP}

Kekerasan terhadap anak memerlukan perhatian semua pihak. Hal ini dikarenakan kekerasan terhadap anak mempunyai dampak yang luas dan berjangka panjang. Trauma yang akan dihadapi anak baik itu 


\begin{tabular}{|c|c|c|c|c|}
\hline JURNAL & \multirow{2}{*}{ VOLUME 1 } & NOMOR 2 & HALAMAN 70-141 & $\begin{array}{l}\text { ISSN 2655-8823 }(p) \\
\text { ISSN 2656-1786 }(e)\end{array}$ \\
\hline KOLABORASI RESOLUSI KONFLIK & HALA \\
\hline
\end{tabular}

sebagai korban maupun pelaku akan selalu dibawa sepanjang kehidupannya. Bahkan dalam beberapa kasus, pelaku kekerasan terhadap anak pada masa kecilnya merupakan korban kekerasan. Oleh sebab itu perhatian yang spesifik lebih diperlukan terhadap anak korban kekerasan.

Penanganan terhadap anak korban kekerasan memerlukan model. Model penanganan ini dapat dijadikan acuan dalam memberikan pelayana sosial bagi anak korban kekerasan. Model penagangan terhadap anak korban kekerasan ini dapat dilihat dari cakupan yang tidak hanya bersifat individual dari korban. Akan tetapi juga harus dapat melibatkan kelompok dalam masyarakat untuk membantu menangani anak korban kekerasan. Kelompok dalam masyarakat tersebut lebih kepada anak-anak baik yang menjadi korban kekerasan maupun yang tidak. Selain itu model pelayanan bagi anak korban kekerasan juga harus berkesimanbungan. Hal ini bertujuan untuk meminimalisir kejadian kekerasan terhadap anak.

Model pelayanan sosial bagi anak korban kekerasan juga harus melibatkan semua pihak. Pelayanan sosial yang diberikan bagi anak korban tidak terbatas pada satu pihak saja. Pelayanan sosial bagi anak korban kekerasan harus bersifat komprehensif. Dengan kondisi ini diperlukan koordinasi antarinstansi yang memberikan pelayanan bagi anak korban kekerasan. Koordinasi diperlukan agar pelayanan sosial yang diberikan tidak tumpang tindih serta memenuhi kebutuhan akan pelayanan yang diperlukan anak korban kekerasan.

Model pelayanan bagi anak korban kekerasan ini hanyalah sebagai acuan dalam penanganan bagi anak korban kekerasan. Keberhasilan penanganan bagi anak korban kekerasan lebih kepada bagaimana menekan kekerasan yang terjadi. Dengan demikian anak-anak terlepas dari kekerasan dan mendapatkan perlindungan. Jadi dengan demikian pencegahan merupakan hal terbaik bagi anak agar tidak mendapatkan kekerasan.

\section{DAFTAR PUSTAKA}

Apsari, Nurliana Cipta, (2015). Hak Anak, Bandung, Indonesia, Widya Padjadjaran

Kementrian Sosial, Kementrian Pemberdayaan Perempuan dan Perlindungan Anak, Badan Peremcanaan Pembangunan Nasional, Badan Pusat Statistik, UNICEF Indonesia, (2013) Survey Kekerasan terhadap Anak Indonesia Tahun 2013, Laporan Penelitian

Karen K. Kirst-Ashman (2010). Introduction to Social Work \& Social Welfare: Critical Thinking Perspectives, Third Edition, New York, NY Brooks/Cole .

Mulyana, Nandang, Risna Resnawaty, Gigin Basar, (2017), Penanganan Anak Korban Kekerasan, Bandung, Indonesia, Widya Padjadjaran

Mulyana, Nandang, Hetty Krisnani, (2016), Intervensi terhadap Remaja Korban Kriminal, Bandung, Indonesia, Widya Padjadjaran

Mulyana, Nandang, Hetty Krisnani, (2016), Intervensi bagi Remaja Pelaku Kriminal, Bandung, Indonesia, Widya Padjadjaran

Pert, Crishtoper G. (2004). "Social Work Children And Their Families pragmatic Foundation". Oxford University Press.

Spicker, Paul, 1995, Social Policy : Theory and Parctice, Publishing wuth Purpose

Suharto, Edi, 2008, Kebijakan Sosial sebagai Kebijakan Publik, Bandung, CV Alfabeta

Kebijakan Publik, Panduan
Praktis Mengkaji Masalah dan
Kebijakan Sosial, Bandung; CV
Alfabeta
----------, 2006, Kebjakan Sosial,
makalah seminar, Bandung
Undang-Undang Republik Indonesia
Nomor 35 tahun 2014 tentang




\begin{tabular}{|c|c|c|c|c|}
\hline JURNAL & \multirow{2}{*}{ VOLUME 1 } & NOMOR 2 & HALAMAN 70-141 & $\begin{array}{c}\text { ISSN 2655-8823 }(p) \\
\text { ISSN 2656-1786 }(e)\end{array}$ \\
\hline
\end{tabular}

Perubahan Atas Undang-undang Republik Indonesia Nomor 23 Tahun 2002 Tentang Perlindungan Anak.

Undang-Undang Republik Indonesia Nomor 11 Tahun 2012 Tentang Sistem Peradilan Pidana Anak.

Undang-undang Republik Indonesia Nomor 23 Tahun 2002 Tentang Perlindungan Anak.

Undang-Undang Nomor 35 Tahun 2014 tentang Perubahan Atas UndangUndang Nomor 23 Tahun 2002 tentang Perlindungan Anak,

Undang-Undang Republik Indonesia Nomor 39 Tahun 1999 Tentang Hak Asasi Manusia.

\section{United Nations Convention on the Rights} of the Child, Tahun 1989

Wibhawa, Budhi, Nandang Mulyana, (2016)

Masalah Sosial Kontemporer, Bandung, Indonesia, Niaga Muda

Wikipedia Bahasa Indonesia, ensiklopedia bebas. Terakhir diunggah pada 07:09, 7 Oktober 2010. Diakses tanggal 23 Januari 2011

www. Kompas.com, diakses tanggal 20 Mei 2016.

www. Kompas.com, diakses tanggal 10 Mei 2016.

www.news.liputan6 .com diakses 20

Januari 2018

www.friedenspaedagogik.de/content/pdf/2

754 diakses 07 Juni 2017

www.rightsvoiceofchildren.blogspot.co.id/

2008/06/convention-on-rights-of-child-

konvensi.html\#.Wm7106inHIU

diakses 20 Juni 2017

http://www.friedenspaedagogik.de/content /pdf/2754 diakses 24 Juli 2017

www.kpai.go.id/ diakses 23 Agustus 2017 Zastrow, Charles and Karen K. KirstAshman. (2007) Understanding Human Behavior and Social Environment. 7th edition. Thomson Brooks/Cole, a part of The Thomson Corporation. 